Dicle Tıp Dergisi / Dicle Med J (2019) 46 (1) : 141 - 147

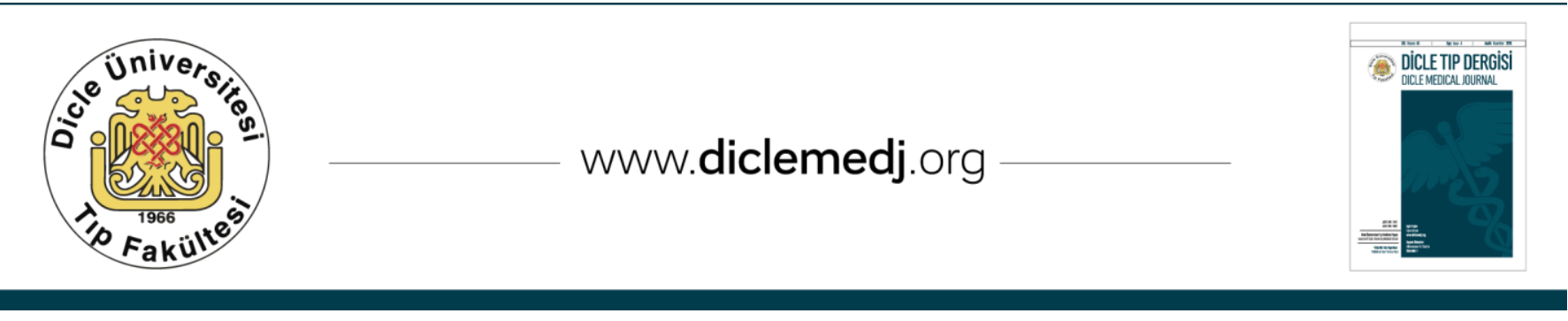

Original Article / Özgün Araștırma

\title{
Survival outcomes in patients with undifferentiated endometrial carcinoma
}

\author{
Alpaslan Kaban', Samet Topuz ${ }^{2}$ \\ 1 Gynecologic Oncology Healt Science University, Istanbul Education Research Hospital, İstanbul, Turkey ORCID: 0000-0002-3623-7240 \\ 2 Faculty of Medicine, Dept. Of Obstetrics and Gynecology, Division of Gynecologic Oncology, Istanbul Univ, Istanbul Turkey ORCID: 0000-0002-9069-0185
}

Received: 26.11.2018; Revised: 23.01.2019; Accepted: 29.01.2019

\begin{abstract}
Objective: The aim of this study was to investigate the clinicopathological features and survival of patients with undifferentiated endometrial carcinoma (UEC).

Methods: Patients who were operated between 2006 and 2014 for endometrial cancer (EC) in the same center were retrospectively reviewed from the clinical archive. Data were obtained from patient files. Survival curves and rates were calculated using the Kaplan-Meier method, and differences in survival were evaluated using the Log-Rank test.

Results: In this study, 774 patients with EC were screened. According to the pathology report, 14 (1.8\%) had undifferentiated type histology. The mean age, parity and body mass index (BMI) of the patients were 58.6 year (range 40-73); 3.28 (range 0-6) and $32.1 \mathrm{~kg} / \mathrm{m} 2$ (range 22.8-41.7), respectively. Of the patients, 64\% (n=9) had deep myometrial invasion, 93\% (n=13) had lymphovascular space invasion, and 57\% (n=8) had cervical involvement. Tumor size was greater than $5 \mathrm{~cm}$ in $64 \%(\mathrm{n}=9)$ of the patients. Thirty five percent $(\mathrm{n}=5)$ of the patients were stage $1 \mathrm{~A}, 21 \%(\mathrm{n}=3)$ were stage $1 \mathrm{~B}, 14 \%(\mathrm{n}=2)$ were stage $2,14 \%$ were stage $3 \mathrm{C}$, and $14 \%$ were stage 4 . As adjuvant therapy, $21 \%(n=3)$ of the patients received chemotherapy only, 14\% $(n=2)$ received radiotherapy only, and $57 \%$ $(n=8)$ received chemotherapy and radiotherapy together. The mean follow-up duration was 36 months (range 4-104). In this period, survival rates were $77 \%$ for early-stage (FIGO 1-2) and $0 \%$ for advanced-stage (FIGO 3-4). The mean survival duration was 81 months in the early stage; 6.8 months in advanced stage (Log Rank test P value= 0.001).

Conclusion: According to this study, UEC is highly associated with pathological poor prognostic factors such as deep myometrial invasion, lymphovascular space invasion, cervical involvement and large tumor size. Patients with advanced stage do not have the chance to survive. Long-term survival is possible if the diagnosis and treatment of the disease is achieved while the tumor is limited to the uterus.
\end{abstract}

Keywords: Undifferentiated, survival, prognosis, surgery, adjuvant treatment.

DOI: 10.5798/dicletip.534852

Yazışma Adresi / Correspondence: Alpaslan Kaban, Gynecologic Oncology Healt Science University, Istanbul Education Research Hospital, İstanbul, Turkeye-mail: alpaslankaban@gmail.com 


\section{Andiferansiye endometrial karsinomlu hastalarda sağ kalım sonuçları}

Öz

Amaç: Çalışmanın amacı, andiferansiye tip histolojideki endometrial karsinomlu (UEC) hastaların klinikopatolojik ve sağkalım özelliklerini incelemektir.

Yöntemler: Aynı merkezde 2006 ve 2014 yılları arasında endometrial kanser (EC) nedeniyle opere edilen hastalar, klinik arşivden retrospektif olarak incelendi. Veriler hasta dosyalarından elde edildi. Sağ kalım süreleri Kaplan-Meier yöntemi kullanılarak hesaplandı ve sağ kalımdaki farklılıklar Log-Rank testi kullanılarak değerlendirildi.

Bulgular: Bu çalışmada, 774 EC hastası tarandı. Patoloji raporuna göre 14'ünde $(\% 1,8)$ UEC tip histoloji saptandı. Hastaların ortalama yaş, parite ve vücut kitle indeksi (VKİ) sırayla 58.6 (40-73), 3.28 (0-6) ve $32.1 \mathrm{~kg} / \mathrm{m} 2$ (22.8-41.7) bulundu. Hastaların \%64'ünde $(\mathrm{n}=9)$ derin miyometriyal invazyon, \%93'ünde $(\mathrm{n}=13)$ lenfovasküler alan invazyonu, \%57'sinde (n=8) servikal tutulum vardı. Tümör boyutu hastaların\%64'ünde (n=9) $5 \mathrm{~cm}$ 'den büyüktü. Hastaların\% 35'i(n=5) evre 1A,\%21'i (n=3) evre 1B, \%14'ü (n=2) evre 2, \%14'ü (n=2) evre 3C ve \%14'ü (n=2) evre 4 idi. Adjuvant tedavi olarak hastaların \%21'i $(n=3)$ sadece kemoterapi aldı, \%14'ü $(n=2)$ sadece radyoterapi aldı ve \%57'si $(n=8)$ kemoterapi ve radyoterapi aldı. Ortalama takip süresi 36 aydı (4-104). Bu dönemde sağ kalım oranları erken evre için \%77 (FIGO 1-2) ve ileri evre için \%0 idi (Şekil 3-4). Ortalama hayatta kalma süresi erken evrede 81 ay,; ileri evrede 6.8 ay bulundu (Log Rank testi P değeri $=0.001$ ).

Sonuç: Bu çalışmaya göre, UEC derin miyometriyal invazyon, lenfovasküler alan invazyonu, servikal tutulum ve büyük tümör boyutu gibi patolojik kötü prognostik faktörlerle ilişkilidir. İleri evreli hastalar hayatta kalma şansına sahip değildir. Uzun süreli sağ kalım, tümör uterusa sınırlıyken hastalığın teşhisi ve tedavisi gerçekleștirilirse mümkündür.

Anahtar kelimeler: Andiferansiye tip, sağ kalım, prognoz, cerrahi, adjuvant tedavi.

\section{INTRODUCTION}

Undifferentiated carcinoma of the endometrium (UEC) is a rare and poorly understood hystological subtype with poor prognosis of endometrial cancers ${ }^{1}$. Currently, a few studies are available in the literature, in which the tumor has been usually investigated through histopathological or molecular perspective ${ }^{2-7}$. The World Health Organization defines it as a malignant tumor of epithelial structure that is too poorly differentiated to be placed in any other category of carcinomas ${ }^{8}$. Some authors claim that it is underrecognizable due to difficulty of its diagnosis, in fact it may be about $9 \%$ of all endometrial cancers ${ }^{4,9}$. The National Comprehensive Cancer Network (NCCN) guideline incorporates this histological subtype into high-risk endometrial cancers and recommends comprehensive staging surgery in the surgical treatment ${ }^{10}$. There is no consensus on adjuvant treatment.
In this study, we investigated the clinicopathological and survey characteristics of patients with UEC.

\section{METHODS}

For the study data, hospital records of 774 patients, who had undergone surgical treatment for endometrial cancer between January 2006 and December 2014 in same gynecological oncology clinic, were reviewed. The inclusion criteria to the study were defined as having a diagnosis of UEC according to the final pathology report. Pathological examination of the patients was reviewed by the same team of gynecopathologists.

A total of 14 patients (1.8\%) diagnosed with UEC based on patients' files in clinic archive were identified. Age, parity, BMI (body mass index), chronic diseases (diabetes mellitus and hypertension), the results of surgical treatment, adjuvant treatment information and pathological examination were retrieved from the patients files. Based on the results, patients 
were restaged according to the International Federation of Gynecology and Obstetrics (FIGO) 2009 criteria.

Follow-up information, disease-free survival durations (DFS) and overall survival (OS) durations of patients were calculated.

Follow-up period was considered as the time between surgery and the time that the patient was last examined (death or last visit). DFS was calculated from the date of surgery to the date of the first evidence of clinical recurrence or death. OS was calculated from the date of surgery to the date of death.

\section{Statistical Analyses}

While evaluating the findings, statistical analyses were done using NCSS (Number Cruncher Statistical System) 2007. In addition to the descriptive methods (Mean, Standard deviation, frequency) used for the evaluation of study data, Kaplan-Meier method was used for survival analysis and Log Rank test was used for the evaluation according to the stages. Results were evaluated within 95\% confidence interval and at a significance level of $\mathrm{p}<0.05$.

\section{RESULTS}

A total of 14 patients were enrolled. The mean age, parity and BMI of the patients were 58.6 years (range 40-73); 3.28 (range 0-6) and 32.1 $\mathrm{kg} / \mathrm{m} 2$ (range 22.8-41.7), respectively. Of the patients, $35.7 \%$ had diabetes mellitus, $57.1 \%$ $(n=8)$ had hypertension and 29.6\% $(n=4)$ had both hypertension and diabetes mellitus (Table1).

Pelvic lymphadenectomy alone was performed in $64.3 \%(n=9)$ of the patients, whereas pelvic and paraaortic lymphadenectomy was performed in $28.6 \% \quad(n=4)$. Paraaortic lymphadenectomy could not be performed in other patients due to morbid obesity, severe comorbidity and technical difficulties (Mean BMI of study group: $32.1 \mathrm{~kg} / \mathrm{m} 2$ ).
Table 1: Patient characteristics.

\begin{tabular}{|lll|}
\hline Feature & $\%$ & $\mathrm{~N}$ \\
Age (year), mean; min-max & 58.6 & $40-73$ \\
Parite $n$, mean; min-max & 3.2 & $0-6$ \\
BMI ( kg/m2), mean; min-max & 32.1 & $22.8-41.7$ \\
Diabetes mellitus (DM) \%, $n$ & 35.7 & 5 \\
Hypertension(HT) \%, $n$ & 57.1 & 8 \\
DM plus HT \%, $n$ & 28.6 & 4 \\
Follow up (month) mean; min-max & 36.0 & $4-104$ \\
Alive \%, $n$ & 50 & 7 \\
Dead \%, n & 50 & 7 \\
Recurrences \%, n & 50 & 7 \\
OS (month), mean \pm sd, min-max & $54.7 \pm 13$ & $4-104$ \\
DFS (month), mean \pm sd, min-max & $32.2 \pm 7.4$ & $3-104$ \\
\hline
\end{tabular}

BMI: body mass index; OS: overall survival; DFS: disease-free survival; min: minimum; max: maximum

Pelvic and pelvic+paraaortic nodal metastasis was determined in \%21.4 $(n=3)$ and \%7.1 $(n=1)$ of the patients, respectively. Of the patients, $21.4 \%(n=3)$ had adnexial metastasis; $7.1 \%(\mathrm{n}=1)$ had omentum metastasis; and 7.1\% $(\mathrm{n}=1)$ had positive peritoneal cytology. Myometrial invasion was greater than half in $\% 64.3 \quad(n=9)$ of the patients. The rate of patients with a tumor diameter less than $2 \mathrm{~cm}$, $2-5 \mathrm{~cm}$, and greater than $5 \mathrm{~cm}$ were $7.1 \%(\mathrm{n}=1)$, $21.5 \%(n=3)$ and $64.2 \%(n=9)$, respectively. Lymphovascular space involvement (LVSI) was present in $92.8 \% \quad(n=13)$ of the patients, whereas $7.1 \%(n=1)$ of the patients had no information on LVSI. Involvement of cervical glanduler involvement alone was determined in $14.2 \% \quad(n=2)$ and cervical stromal involvement was determined in $42.9 \%(n=6)$ of the patients. The clinical features and FIGO stages of the patients were presented in Table 2

As the adjuvant therapy, $21.5 \%$ (3) of the patients received chemotherapy alone, $14.2 \%$ (2) received radiotherapy alone, and 57.1\% (8) received chemotherapy together with 
radiotherapy. Information on adjuvant therapy was not available for one patient. Adjuvant therapy options were similar in alive and dead patients (Table 2).

\section{Survey Analysis}

The mean follow-up period was 36.0 months (range 4-104). Of the patients, 50\% $(n=7)$ were alive and $50 \%(n=7)$ had died during this follow-up period. Mean OS duration was 54.7 \pm 13.0 months (Table 1, Figure 1).

\section{Disease-free survival}

Recurrences were encountered in $50 \%(n=7)$ of the patients. The mean DFS was $32.2 \pm 7.4$ months. The latest recurrence was seen on the 9th month, and cumulative DFS rate on that month was $50.0 \%$ with standard error of $1.34 \%$ (Table 1, Figure 2).

\section{Subgroup analysis according to FIGO stage}

Of 9 patients with stage $1 \& 2,7$ (77.8\%) were alive and 2 were dead. The latest death occurred on the 32nd month; cumulative survival rate on that month was $71.1 \%$ with standard error of $18 \%$ (Table 3, Figure 3). All patients in stage $3 \& 4$ died. The mean survival time was $6.8 \pm 1.3$ months (Figure 3 ). There was a statistically significant difference between survival durations (Log Rank test P : 0.001) (Table 3).
Table 2: Clinicopathologic features.

\begin{tabular}{|c|c|c|}
\hline Characteristics & $\%$ & $n$ \\
\hline \multicolumn{3}{|l|}{ FIGO stage } \\
\hline $1 A$ & 35.7 & 5 \\
\hline $1 B$ & 21.4 & 3 \\
\hline 2 & 14.2 & 2 \\
\hline $3 C$ & 14.2 & 2 \\
\hline 4 & 14.2 & 2 \\
\hline \multicolumn{3}{|l|}{ Surgery } \\
\hline Hysterectomy and BSO & 100 & 14 \\
\hline Lymphadenectomy & 92.9 & 13 \\
\hline Only pelvic $L N D$ & 64.3 & 9 \\
\hline Pelvic+paraaortic LND & 28.6 & 4 \\
\hline \multicolumn{3}{|l|}{ Metastases } \\
\hline Only Pelvic LNM & 21.4 & 3 \\
\hline Pelvic+Paraaortic LNM & 7.1 & 1 \\
\hline Over/tuba metastasis & 21.4 & 3 \\
\hline Omentum metastasis & 7.1 & 1 \\
\hline Positive peritoneal cytology & 7.1 & 1 \\
\hline \multicolumn{3}{|l|}{ Myometrial invasion } \\
\hline$\leq 50 \%$ & 35.7 & 5 \\
\hline$>\% 50$ & 64.2 & 9 \\
\hline \multicolumn{3}{|l|}{ Tumor size* } \\
\hline$<2 \mathrm{~cm}$ & 7.1 & 1 \\
\hline $2-5 \mathrm{~cm}$ & 21.5 & 3 \\
\hline$>5 \mathrm{~cm}$ & 64.2 & 9 \\
\hline Unknown & 7.1 & 1 \\
\hline \multicolumn{3}{|l|}{ LVSI } \\
\hline Present & 92.8 & 13 \\
\hline Unknown & 7.2 & 1 \\
\hline \multicolumn{3}{|l|}{ Cervical invasion } \\
\hline Gland & 14.2 & 2 \\
\hline Stroma & 42.9 & 6 \\
\hline \multicolumn{3}{|l|}{ Adjuvant therapy } \\
\hline Chemotherapy only & 21.5 & 3 \\
\hline Radiotherapy only & 14.2 & 2 \\
\hline Chemo\&radiotherapy & 57.1 & 8 \\
\hline Unknown & 7.1 & 1 \\
\hline
\end{tabular}

FIGO: International Federation of Gynecology and Obstetrics; BSO: Bilateral salpingo-oophorectomy; LND: Lymph node dissection; LNM: Lymph node metastasis; LVSI: Lymphovascular space involvement; *: largest diameter 
Table 3: Overall survival durations according to the stage of disease.

\begin{tabular}{|lccccc|}
\hline FIGO stage & $N$ & Dead & Alive & OS (month) Mean \pm sd & Pvalue $^{*}$ \\
\hline $\begin{array}{l}\text { Early } \\
\text { (Stage 1-2) }\end{array}$ & 9 & 2 & 7 & $81.31 \pm 13.86$ & \\
$\begin{array}{l}\text { Advanced } \\
\text { (Stage 3-4) }\end{array}$ & 5 & 5 & 0 & $6.80 \pm 1.39$ & $\mathbf{0 . 0 0 1}$ \\
\hline
\end{tabular}

*Kaplan-Meier Analysis OS: overall survival

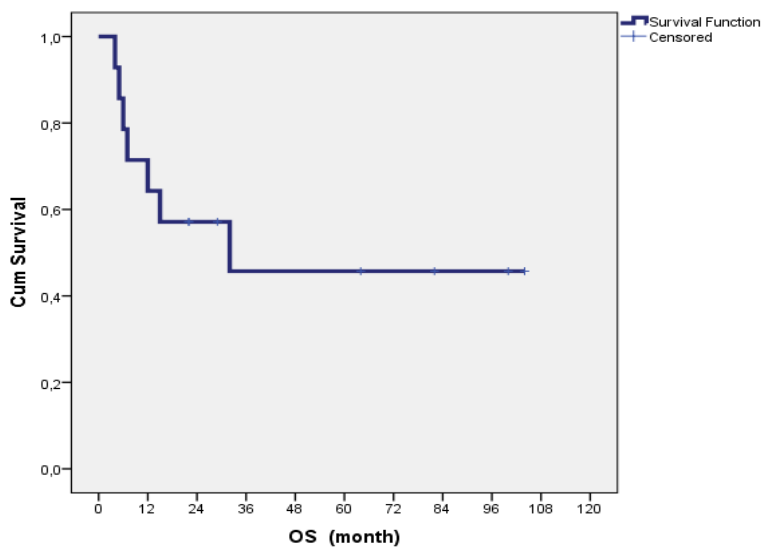

Figure 1: Overall survival graphic

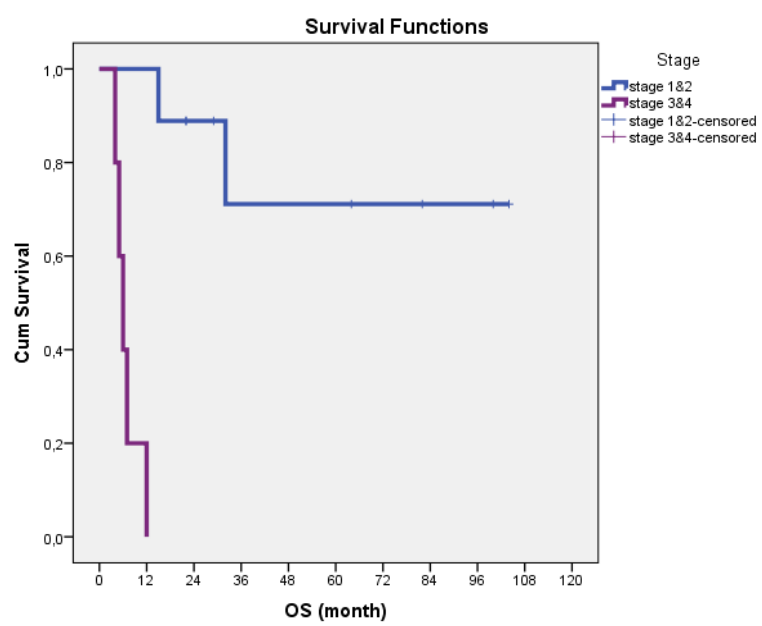

Figure 2: Disease-free survival graphic.

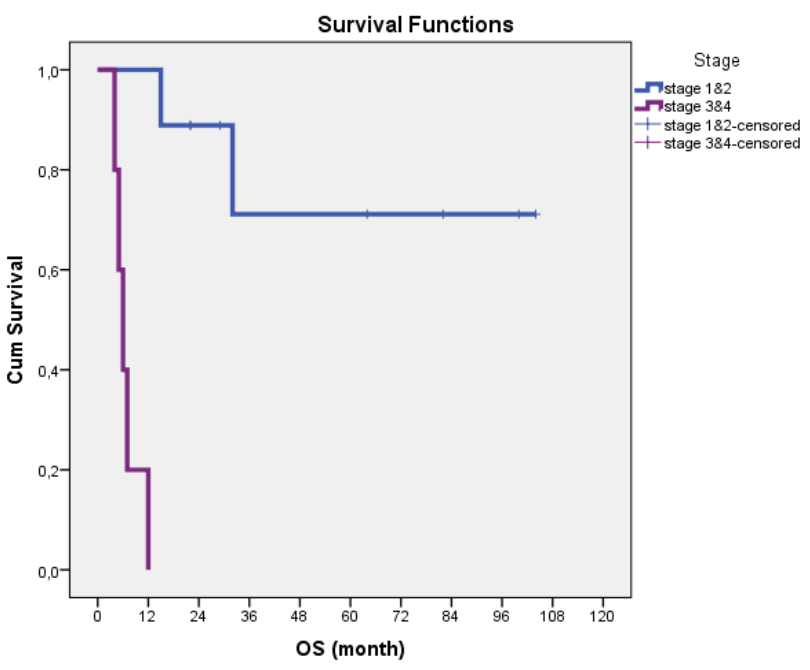

Figure 3: Survival curve according to the stages

\section{DISCUSSION}

In the literature, UECs are described as rarely encountered endometrial cancers with poor prognosis 4 . In the present study, the prevalence of UEC was $1.8 \%$ among patients with endometrial cancer. The mean age of the patients was 58.6 years.

Most of the endometrial cancers are diagnosed early due to unexpected vaginal bleeding or bleeding disorder. Early diagnosis of patients with UEC seems to be low. Tafe et all. ${ }^{9}$ conducted a study in 26 UEC patients and reported that $58 \%$ of the patients were in Stage 3-4 at diagnosis. In the study conducted by Altrabulsi et all. ${ }^{3}$ with 16 UEC patients, 54\% of UECs presented as advanced-stage disease (stage III or IV). In the present study, $71.6 \%$ of UEC patients were stage $1-2$ and $28.4 \%$ were stage 3-4. The high rate of advanced stage in the diagnosis reflects the rapidly progressive and aggressive nature of the tumor.

It is assumed that rapidly-growing aggressive tumors would response to chemotherapy better ${ }^{11}$. However, UECs show poor response to chemotherapy. In the present study, all of 7 patients that died have received chemotherapy (4 of them received chemotherapy together with radiotherapy). The mean DFS in the 
patients died was 4.5 months (range 3-9). These patients relapsed while receiving chemotherapy. The literature includes a case report, in which tetrahydropyranyl-adriamycin (THP), paclitaxel, and carboplatin regimen has been successfully used as an alternative chemotherapy regimen. In this case report, Hayashi et al. declared that they observed 41month survival using this regimen in an advanced-stage patient ${ }^{12}$. We found no other study performed later using this chemotherapy regimen in UEC patients. To date, there is no consensus on the optimal chemotherapy for this type of carcinoma.

Tumor size is another parameter that has been investigated in the present study. Tumor size (the longest measurement) was greater than 5 $\mathrm{cm}$ in $64.2 \%$ of the patients (Table 2). This measurement, which is the tumor size at the time of surgery, can be considered as another sign indicating a tumor's rapidly-growing potential. We think that the tumor continued to grow rapidly until the time of surgery. At this point, treating patients diagnosed with UEC as soon as possible and identifying them as the patient group with priority in the clinic can be critical for survival.

Deep myometrial invasion, LVSI and cervical invasion (mucosa/stroma) rates of the patients were $64.2 \%, \% 93.8 \%$ and $57.1 \%$, respectively (Table 2). These pathological data reflects the aggressive nature of tumor.

Based on the present study, no patient was alive in the presence of extrauterine metastasis. However, OS rate was $77.8 \%$ and mean OS was 81.3 months in the disease limited to the uterus. Besides, there was no patient "alive with disease" in the study population. None of the patients with recurrence had survived.

In conclusion, both aggressive nature of the tumor, advanced stage at diagnosis, and unresponsiveness to adjuvant therapy are probable causes of poor prognosis in UEC patients. When we divided the patients according to their stages, patients in advanced stage had no chance of survival, patients died in several months. However, there was an unexpected long survival in stage 1-2. The factor that positively affects the survival of these patients seems to be surgical treatment when the disease is limited to the uterus.

Declaration of Conflicting Interests: The authors declare that they have no conflict of interest.

Financial Disclosure: No financial support was received.

\section{REFERENCES}

1. Acharya S, Hensley ML, Montag AC, Fleming GF. Rare uterine cancers. Vol. 6, Lancet Oncology. 2005. p. 96171.

2. Ramalingam P, Masand RP, Euscher ED, Malpica A. Undifferentiated Carcinoma of the Endometrium: An Expanded Immunohistochemical Analysis Including PAX-8 and Basal-Like Carcinoma Surrogate Markers. Int J Gynecol Pathol. 2016; 35: 410-8.

3. Altrabulsi B, Malpica A, Deavers MT, et all. Undifferentiated carcinoma of the endometrium. Am J Surg Pathol. 2005; 29: 1316-21.

4. Silva EG, Deavers MT, Malpica A. Undifferentiated carcinoma of the endometrium: A review. Pathology. 2007; 39: 134-8.

5. Abeler VM, Nesland JM, Kjell E. Kjorstad. Undifferentiated carcinoma of the endometrium. A histopathologic and clinical study of 31 cases. Cancer. 1991; 68: 98-105.

6. Garg K, Soslow RA. Endometrial undifferentiated carcinomas. Pathology Case Reviews. 2011.

7. Espinosa I, Lee CH, D'Angelo E, Palacios J, Prat J. Undifferentiated and Dedifferentiated Endometrial Carcinomas With POLE Exonuclease Domain Mutations Have a Favorable Prognosis. Am J Surg Pathol. 2017 Aug; 41: 1121-8.

8. Eble, John N., Fattaneh A. Tavassoli, and Peter Devilee, eds. Pathology and Genetics of Tumours of the Breast and Female Genital Organs. Iarc, 2003. 
9. Tafe LJ, Garg K, Chew I, Tornos C, Soslow RA. Endometrial and ovarian carcinomas with undifferentiated components: Clinically aggressive and frequently underrecognized neoplasms. Mod Pathol. 2010; 23: 781-9.

10. Koh WJ, Abu-Rustum NR, Bean S, et al. Uterine Neoplasms, Version 1.2018: Clinical practice guidelines in oncology. JNCCN Journal of the National Comprehensive Cancer Network. 2018.
11. Markman M. General principles: chemotherapy. In: Berek JS HN, editor. Practical Gynaecologic Oncology. Lipincott Williams and Wilkins; 2004. p. 91.

12. Hayashi $M$, Ueda $Y$, Takimoto $T$, Ohkura $T$. Undifferentiated endometrial carcinoma of the uterus: marked effect of chemotherapy with tetrahydropyranyl-adriamycin, paclitaxel, and carboplatin. Int J Gynecol Cancer. 2004; 14: 388-94 